Алекос

Алаванос
Шест прашања за грчката криза што се тешки за одговарање ${ }^{1}$
Alekos

Alavanos

\section{Six Questions on the Greek Crisis that are Difficult to Answer ${ }^{1}$}

\section{Биографска белешка}

Александрос 'Алекос' Алаванос е грчки политичар, поранешен член на грчкиот парламент и на европскиот парламент. Од 2004 до 2008 беше претседател на Коалицијата на левицата на Движењатаи екологијата, позната како Синаспизмос. Тој беше парламентарен лидер на пошироката Коалиција на радикалната левица (СИРИЗА). Сега е активен во политичкото движење План Б.

Мислам дека треба да направиме мала промена во агендата бидејќи вчера веќе имавме дискусија за овие три прашање: првото беше, можеме ли да се надеваме на промена во Европа што ќе ѝ помогне на Грција, како и на други земји, но особено на Грција како на екстремен случај? Второто, ќе се разреши ли ситуацијата по конфронтирањето со ЕУ или уште повеќе ќе се искомплицираат работите? Третото, дали ако една земја се повлече од ЕУ, тоа може да

1 Транскрипција на предавањето одржано на 28 март 2015 во рамките на „Школата за политика и критика 2015“ организирана од Институт за општествени и хуманистички науки - Скопје со поддршка од фондацијата Роза Луксембург - Југоисточна Европа. Предавањето беше одржано пред договорот меѓу владата на СиризаАнел со Тројката - ЕК, ЕЦБ и ММФ за продолжување на меморандумот за спас на почетокот на јули 2016.

\section{Bionote}

Alexandros 'Alekos' Alavanos is a Greek politician, former member of the Hellenic Parliament and the European Parliament. From 2004 until 2008 he was president of the Coalition of the Left of Movements and Ecology, commonly known as Synaspismos. He was parliamentary leader of the wider Coalition of the Radical Left (SYRIZA). Now he is active in the political movement Plan B.

I think we have to make a small change in the agenda because yesterday we already have had some discussion about these three questions, which are the following: The first question is - can we hope for a change in Europe that will be helpful for Greece and for other countries, especially Greece as an extreme crisis case? The second question is - is there a solution after a confrontation with EU or the things will be more difficult? And the third question is - if a country would withdraw from EU it could be a step to the past, closing its national boundaries, becoming nationalistic, leaving aside all internationalist

1 Transcription of a lecture given on March 28th 2015, within the framework of "The School of Politic and Critique 2015" organized by ISSHS with the support of Rosa Luxemburg Foundation-Southeast Europe.The lecture was before the agreement of Syriza-Anel government with the troika EZ - ECB - IMF for the continuation of the bail out program (memorandum) at the beginning of July 2016. 
значи чекор наназад, затворање на државните граници, државните доброволци во меѓународни позиции? Ке ги имаме на ум овие прашања, но сега имам шест поенти што сакам да ги разгледаме и ќе се обидам да бидам пососредоточен. Ви благодарам за храброста што дојдовте [се смее].

\section{Прво, Едип и Големата грчка депресија}

Првата поента ќе биде малку поразлична од вчерашната дискусија. Се однесува на една приказна од грчката митологија. Многумина од вас знаете за Едиповиот комплекс, за синот и мајката. Сакам да ви го раскажам овој мит. „Едип“ е една од најдобрите трагедии на поетот Софокле. Теба била еден од најпознатите градови на Древна Грција. Се наоѓала северозападно од Атина. Имала добар крал. Се викал Лај, бил оженет за Јокаста. Тие, се чини, биле бездетни.

Еднаш, Лај патувал со кочијата, или преведено во денешно време, со автомобилот. Тој се пресретнал со еден маж со кого се скарале кој прв да му се тргне од патот на другиот. Лај многу се налутил затоа што како крал сметал дека младичот не му се обраќа како што треба. Бил многу агресивен, почнале да се караат и младичот го убил Лај не знаејќи кој е. Младичот бил Едип, млад принц од Коринт, Пелопонез, друг град-држава во Древна Грција.

Потоа го продолжил своето патување кон Теба. По пат ја сретнал сфингата. Сфингата било чудовиште што ја тероризирало Теба. Тоа ѝ бил најголем проблем на Теба во тоа време. Ако некој сакал да влезе во градот-држава, сфингата би поставила еден услов, да реши една загатка. Никој дотогаш немал одговорено точно. Која била загатката? Загатката била: Што оди на четири нозе наутро, на две попладне и на три навечер? Едип, младиот принц од Коринт, одговорил дека тоа е човекот. Тој како дете оди на positions? So, ok, we keep these questions in mind but I have now six points including them and I'll try to be less lost than yesterday and I thank you for your courage to be here today and have your English lesson [laughs].

\section{First, Oedipus and the Great Greek Depression}

The first point will be in a way little different from the whole discussion that we had yesterday. It will be about a tale from the Greek mythology. Many of you or all of you know the Oedipus complex, the lessons about the son and the mother. So I want to tell you this myth. That was one of the best tragedies of the poet Sophocles. Thebes was one of the great Ancient Greek cities. It was a little to the north-western from Athens. It had a good king. He was Laius, he was married to Jocasta. They seemed childless.

One time Laius was going on his chariot, we could say his car today, on a trip. He met a man and they had a fight, who of the two will to get out of the way of the other. Laius was very angry because he was the king and he thought the young man did not speak to him in a proper way. He was very aggressive and they started to quarrel and then the young man killed Laius without knowing who he was. This young man was Oedipus, a young prince coming from Corinth, Peloponnese, another city state of Ancient Greece.

He continued his travel to Thebes. On the way to Thebes he met the Sphinx. The Sphinx was a monster that was terrorising Thebes and that was the main problem of Thebes at the time. If anyone wanted to enter the citystate the Sphinx would give only one condition - if he gives a proper answer to the riddle. No one until that time had the possibility to give the right answer. What was the riddle? The riddle was "what walks in four feet in the morning, two in the afternoon and three at night?" So Oedipus, the young prince from Corinth, answered 
четири - ползи, кога е возрасен, оди на две нозе, а во поодминати години оди на три, се служи со бастун. Едип победил. Патот се распослал пред него и цела Теба била ослободена. Жителите на Теба слушнале за смртта на Лај и решиле крал да им биде оној што ги ослободил од сфингата. Така, Едип станал крал на Теба и се оженил за вдовицата Јокаста, жената на претходниот крал на Теба. Тие добиле два сина и две ќерки.

Тоа бил прекрасен период за Теба. Едип бил добар и праведен крал. Сѐ било супер. Одеднаш, нештата се смениле драстично. За кралот промената била драматична. Теба ја погодила голема чума што ја убила стоката, ги уништила посевите и луѓето. Теба станала град на болести. Тебанците отишле кај пророчиштето во Делфи да побараат помош. Пророчиштето одговорило дека убиецот на Лај живее во Теба и дека чумата ќе продолжи да коси сѐ додека тој не замине од Теба. Сите биле изненадени и никој не верувал дека убиецот на Лај е во Теба. Кралот се обидел да го најде убиецот. По многу истраги, нашле еден стар слуга на Лај. Тој им кажал дека кога на Лај и Јокаста им се родило првото дете, Пророчиштето во Делфи прорекло дека детето ќе го убие својот татко, ќе се ожени за својата мајка и ќе им навлече несреќа на сите. Затоа, Лај му го дал нему детето за да го убие. Тој не сакал да го убие двеседмичното момче, па му го дал на пријател што работел како слуга кај кралот на Коринт. Слугата му го дал Едип на кралот на Коринт кој го усвоил како син и тој потоа дошол во Теба.

Кога се расчуло ова низ палатата и дознале кралот и сите други, никој не можел да поверува. Но, тоа било град, ова било несреќа. Било нешто сосем ненадејно. Cè се сменило, особено за семејството на кралот. that it is the man. When one is a child it is on its four, crawling, when one is an adult on two and when a man is of old age he has a third foot, a stick. So he won, the way was open for him and for everyone as Thebes was freed. The Theban citizens heard about Laius' death and decided that their king would be the one who liberated them from the Sphinx. So, Oedipus became a king of Thebes and he married the widow Jocasta, the wife of the previous king of Thebes. They had two sons and two daughters.

Then there was a wonderful time for Thebes. Oedipus was a very good and just king. Everything was great. But, suddenly things changed dramatically. It was a dramatic change for the king as well. Thebes was hit by a great plague that killed the livestock, the crops, and the people. Thebes was a city of the sick. The Thebans went to the oracle in Delphi asking for help. The oracle answered that the killer of Laius was living in Thebes and that the plague will remain unless he leaves Thebes. Everyone was surprised and no one believed that the killer of Laius was in Thebes. The king launched an attempt to find the killer. After much investigation, they found a very old servant of Laius. He told them that Laius and Jocasta had one first child but the oracle in Delphi prophesied that that the child will kill his father, marry his mother and bring disaster to everyone. So this child was given to this servant of Laius to kill him. He could not kill the boy of two weeks of life so he gave him to his friend who was a servant to the king of Corinth. So this servant gave Oedipus to the Corinthian king and he adopted him as a son and it was he who came to Thebes.

When this was announced in the palace before the king and the others, no one could believe it. But it was truth. So, for the king, his family and the whole city it was a disaster. It was something very sudden. Everything changed especially for the king's family. So, the king 
Кралот дознал дека тој бил убиецот на легитимниот крал, убиецот на Лај, на својот татко. Дознал дека сопругата му е всушност мајка и дека тој направил инцест. Кралот дознал дека неговите деца се деца на неговата мајка, што значи дека се негови браќа и сестри. Сѐ било лудо, секој концепт го загубил значењето. Неговата жена-мајка се самоубила, неговите два сина се убиле меѓусебно. Керка му, Антигона, се самоубила, а кралот се ослепел и ја оставил Теба на помладата ќерка-сестра.

Зошто ви ја кажувам оваа приказна? Затоа што друга приказна, не сосем истата, но со исто значење, ја искористи во многу добар говор многу познат американски антрополог, Грегори Бејтсон (Gregory Bateson) во политички говор за Версајскиот договор што ја прекинал Првата светска војна. Договорот бил многу остар за Германија и му наметнал на народот големи долгови. Поентата што се обиде тој да ја извлече од трагедијата за германската ситуација беше дека во луда ситуација и луѓето полудуваат. Не знаат зошто имаат толку многу проблеми. Луѓето не знаат зошто би биле тие виновни и одговорни затоа што не направил ништо Едип; бил добар човек. Значи, сфатил дека начинот на кој биле поставени стварите ја предизвикал лудата ситуација.

За Германците, болната ситуација настанала кога биле поразени во Првата светска војна, особено поради посебната одговорност на Соединетите Американски Држави. Имено, претседателот Вилсон ветил дека САД ќе ги почитуваат сите во договорот и дека иако Германија ја изгубила војната, ќе ѝ помогнат со развојот и обновувањето на економијата, итн.

Може да се каже дека е исто во Грција, и така и ќе остане, бидејќ́ луѓето не знаат, не можат да разберат за што се работи, не знаат како да се извлечат од ситуацијата. Стануваат ирационални, агресив- found out that was the killer of the legal king, the killer of Laius - his father. The king found out that his wife was his mother, that he made adultery. The king found that his own children were a children of his mother, which means they were also his siblings. So everything was crazy, every concept had lost its meaning. His wife mother committed suicide, she killed herself and his two sons - brothers killed each other. His daughter sister, Antigone, killed herself and the king blinded himself and he left Thebes with the surviving the younger daughter - sister.

Why am I telling this tale? Because another tale, not exactly the same but with the same meaning was used in very good speech by a very known American anthropologist, Gregory Bateson in a political speech about the Versailles treaty that ended the World War I. The treaty was very harsh towards Germany and burdened its people with very strong debts. The meaning he tried to draw from the tragedy about the German situation was that in a crazy situations, when the meaning has been lost or totally confused for everyone, the people themselves become crazy. They don't know why they have all the problems, what is the cause, why they are punished so severely. They don't know why they are guilty and responsible because they are like Oedipus who had done nothing, he was a good man also. But he found that the way the things were placed in the world created the crazy situation.

So, this painful situation was with the German people after they were defeated in the World War I, especially with the special responsibility of the United States. It was an American, the United States President Wilson, who had promised that "ok, we will have a respect for everyone in the treaty, ok you have lost the war but we will help you with your development and the reconstruction of the economy, of Germany etc." 
ни и еден од главните феномени за оваа промена на однесувањето е присуството на неонацизмот во грчката политика, што претставува проблем. Никому не му се веруваше затоа што и кога беа нацистите присутни таму, немаа силна поддршка од голем дел од општеството. Сѐ до постојната криза нацистичките идеи немаа сериозно влијание.

Ако некој може да најде смисла во оваа ситуација, а не може да им помогне на луѓето да разберат зошто се случува тоа што се случува, од која причина и што треба да се прави, тогаш само уште повеќе ќе се заглавува во оваа лоша позиција. Ова е многу важно не само за главните партии на опозицијата, туку и за радикалната левица. Ако радикалната левица им помогне да разберат: што е причината, каква била еволуцијата, што треба да се направи, тогаш, во ред, ке се извлечат од ситуацијата. Ако радикалната левица ги збунува, тогаш лошата ситуација ќе опстане. Не може да има никакво оправдување, да ние сме левичари, имаме добри намери. Мислам дека дури и главните партии имаат добри намери - сепак тие не се вампири или ѓаволи што сакаат да му ја исцицаат крвта на работниот народ - тие се заробени во европските концепти и политики што ги влошуваат наместо да ги решаваат проблемите. Сметам дека ова е еден од главните проблеми и на Сириза денес. Случајот на Варуфакис, министерот за економија, е карактеристичен за конфузијата што ја создаваат политиките на Сириза.

Ако некој му каже на народот „можеме да го прекинеме штедењето,“ има право. Мора да го прекинеме штедењето. Како до поголемо вработување? Да почнеме да ја реконструираме земјата, но не можеме да го правиме тоа во истиот контекст што ги предизвика овие проблеми без да има конфронтација. Треба да му зборуваме на народот јасно, со отворени карти, без загатки и да им одговориме на нивните
So you can say it's the same in Greece and in any way it remains the same in Greece because people don't know, cannot understand what it is this crisis, everything looks irrational, without clear meaning, they don't know how they can go out of this situation. They are becoming irrational, they are becoming aggressive, they want revenge and punishment and one of the main phenomenon for this change of behaviour is the problem of Neo-Nazis presence in Greek politics. No one could guess that there would be such a reactionary movement in Greece, because even during the Nazi occupation there was not a strong support from a tight part of the society. There has not been, until the present crisis, any serious influence of Nazi ideas.

So, if one cannot construct a reasonable meaning for this extraordinary situation and help the people to understand why this is happening, what the cause is and what has to be done, then there will be more trapping in this irrational position. This is very important not only for the responsibility of the mainstream parties of the opposition but for the radical left, too. If the radical left helps them to understand: what is the cause, who are the guilty, what are the options, what has to be done, then, ok, and there is a chance to step out of the situation. If even the radical left is also confusing the people, then the present, very bad, situation will persist. And there cannot be any justification, yes, but we are left people, we have good intentions. I think, even the mainstream parties have good intentions they are not vampires, devils who want to drink the blood of the working people - they are imprisoned in the European concepts and policies that that aggravate instead of solving the problems. I think this is also main problem with Syriza today. The case of Varoufakis, the Economics Minister, is characteristic of the confusion the Syriza policies create. 
прашања. Поентата што сакам да ја истакнам е дека народот не разбира, се однесува нерационално и стана опасен на некој начин и еден од главните начини на извлекување од кризата е да му се даде смисла на народот за тоа што се случува во Грција сега и да му се даде смисла на излегувањето од ситуацијата. Тоа е првата поента. Другите поенти ќе бидат доста покуси.

\section{Второ, еврозоната како фактор за влошување на кризата}

Второто прашање е: дали Европа може да се смени за наместо да биде фактор за кризата, да биде фактор за решение. Наместо да биде непријател, како денес, да биде близок сојузник? Погрешно е да се мисли дека Европа е неподвижна. Се движи, сѐ се движи и сѐ се менува. Понекогаш оваа промена може да биде во позитивна насока, а понекогаш во негативна. Може ли сега да биде во позитивна насока? Да, со многу мали чекори се движи во позитивна насока. Никој не знае што ќе се случува утре во нестабилниот економски и геополитички меѓународен контекст. Се работи за одлуката на Европската централна банка за квантитативно попуштање, тоа значи поголема монетарна циркулација, повеќе евра, подобра ликвидност, неопходни за економија во рецесија и дефлација. Ова има и спореден резултат, поевтино евро. Ова може да значи, на пример, ова лето, ако македонските државјани решат да одат на одмор во Грција или во Италија, ќе биде поевтино. Ке биде околу 30\% поевтино од минатата година. Грција може да има поголем извоз, помалку увоз, повеќе туризам и подобар надворешен баланс во ситуацијата. Има и трет услов кој не го постави Европа, туку Соединетите Американски држави по технолошките новини во нафтената индустрија, исто така земјите од ОПЕК го продолжија истата испорака на нафта иако побарувачката е многу помала. Тие имаа поголеми залихи
So if one says to the people "we can end austerity," he is right. We must end austerity. We want to help increase employment? Right. Let's start to reconstruct the country, but we can't do in the same context that created these problems, with no confrontation. We have to speak to the people clearly, with open our cards, without riddles, and answer all their questions. So, the point that I would like to stress is that the people cannot understand, the people behave irrationally and can behave in a dangerous way and so one of the main steps to go out of the crisis is to give the people a meaning for what is now going on in Greece and to give a meaning for an exit. That's the first point. The other points will be quite shorter.

\section{Second, Eurozone as a factor of crisis deterioration}

The second question I want to ask is: Can Europe change so that instead of being a factor of the crisis, will be a factor of the solution, instead of being an enemy, like today, becoming a close friend. It would be a mistake to think that Europe is immovable. It's moving, everything is moving, and everything is changing. Sometimes this change could be in positive directions and sometimes in a negative. Can it be now in a positive direction? Yes, with very small steps it is moving in a positive direction. No one knows for tomorrow in the unstable economic and geopolitical international context. First, it is the decision of the European Central Bank for quantitative easing, that means bigger monetary circulation, more euros, better liquidity, necessary for an economy in recession and deflation. This has a secondary result, the cheaper euro. For example - this summer if Macedonian citizens decide to go to Greece for vacation, or to Italy it will be cheaper, it will be something like 30\% cheaper than last year. So Greece can have more exports, less imports, more tourism, and better external balance in the situation. There is also a third positive factor, it was 
на гориво на планетарно ниво, па цената на горивото е многу пониска. Тоа е од помош за секоја економија, особено за европската индустрија.

Значи, има позитивна промена. Не е стабилна, но им помага на земјите што немаа посебни или многу големи проблеми, како на пример, Италија. Таа има проблеми што не се страшни, но не може да им помогне на земји како Грција. Тоа би било позитивно за Грција, но проблемите на Грција се толку сложени и сериозни, што мора да се смени целосно политиката.

За да ја разбереме Европа, мора да разбереме дека таа не е заедница на држави на исто ниво на развој. На пример, во Глобалниот извештај за конкурентност на Светскиот економски форум, прва на списокот е Швајцарија која не е во Европската унија, втор е Сингапур, трети се Соединетите Американски Држави, Финска е четврта, петта е Германија, Италија е на 49, а Грција на 81 место, пред Молдавија и Ел Салвадор. Многу лоша конкурентност, особено после кризата. Вашата земја е на 63. место, тоа е доста подобро од Грција. Пред неколку години беше спротивно. Значи - различен лек за различна болест. Аспиринот е добар за главоболка, но не лекува рак.

Според моето мислење, главната причина за овие разлики е структурниот проблем на Европската унија, а особено еврозоната, каде што постои раздел меѓу центарот и периферијата. Имате центар, или едноставно - извозник, а периферијата е обврзана да биде увозник. Ако нема посебни мерки за овие земји, особено за Грција, како екстремен случај, тогаш им претстои катастрофа. Секако, има надеж за политичка промена во позитивна насока, но иако имаше промени во многу влади на Европската унија, нејзината политика не се смени. На пример, во овие две - три години, во втората најмоќна држава во Ев- not created by Europe but by United States after the technological innovation in the oil industry and by OPEC countries that continue the same oil supply although demand for oil is quite less than the official perspective. They had more supply of oil on a planetary level so it is quite cheaper the oil price. That is very helpful for every economy especially European industries.

So, there is a positive change, it is not stable, it's helpful for countries that have not special problems or very great problems like Italy, for example. It has problems, not very grave. These positive changes, unfortunately, cannot have a strong influence for countries like Greece. They of course are not negative for Greece too but the problems for Greece are so deep, so difficult and so grave that there must be a total, radical change of policy.

In order to understand Europe we must understand that it is not a union of states on the same level of development. For example, the Global Competitiveness Report by the World Economic Forum, the first in this list is Switzerland, it's not in the European Union, the second is Singapore, the third is United States, the fourth is Finland, the fifth is Germany, Italy is $49,{ }^{\text {th }}$ Greece is 81 , th just before Moldova and El Salvador. So, very, very bad competitiveness for us especially after the crisis. Your country is $63,{ }^{\text {rd }}$ so quite better than Greece. Some years ago it was exactly the opposite. So, a different drug for every different illness. Aspirin is good for the headache, it's not the medicine for the cancer.

My opinion is that the main cause for the differences among European states is that the structural problem of the European Union and especially of Eurozone, is a kind of division between centre and periphery. You have a centre, in simple words - exporter, and periphery that is obliged to be an importer. So, if there are not special measures for these countries, and especially for Greece 
ропската унија, Франција, Оланд (Hollande) стана наследник на Саркози (Sarkozy), социјалдемократ по десничар. Истото се случи во Италија, трета земја. Рензи (Renzi) стана наследник на Берлускони (Berlusconi). Имаше промена во Германија. Немаме христијанско-демократска влада со чисто неолиберална идеологија, но имаме христијански демократи со социјалдемократи. Не се случи ама баш никаква промена. Иако овие промени се интересни, тие не создаваат услови за решавање на кризи како таа во Грција.

\section{Трето, политичкото разногласие на европските левичарски сили}

Третата поента - би сакал да нагласам дека ова издвојување придонесува многу радикалните левичарски партии или движења од разни земји да имаат различен став кон Европската унија. Иако, повеќе или помалку, ги имаат истите средства, слични идеологии, се од истото политичко семејство, во истиот тек на европска мисла, итн. Дури и во рамките на една земја можете да имате еден став во дадено време, а потоа друг став, во друго време. Ќе ви дадам личен пример. Кога Грција стануваше членка на Европската унија, бев против тоа затоа што бев комунист. Мнозинството од народот беше за. Се испиша историјата и ние станавме членка на Европската унија. Откако ја напуштивме Комунистичката партија и ги создадовме Синасписмос (Synaspismos) и Сириза, сфативме дека мора да се скараме со другите комунистички левичарски партии, радикални партии, итн., за да можеме да имаме реформи во Европската унија. Заборавивме дека не го поддржувавме интегрирањето на Европската унија, особено еврозоната. Најлудо е што беше многу силно и ненадејно, особено теоретски гледано; многумина економисти и тоа добри економисти, како професорите Мариолис (Mariolis) и Лапавитас (Lapavitas), as an extreme and extraordinary case, then they are going towards a disaster. Of course, some have a hope for a European level political change in a positive direction but although there were changes in many governments of European Union, there was no essential change in its policy. For an example, in these two-three years, in the second powerful state of European Union - France, Sarkozy was succeeded by Holland, a rightist by socialdemocrat. It is the same in Italy, the third country. Berlusconi was succeeded by Renzi. We had a change in Germany. We don't have a Government of ChristianDemocrats with mere neoliberal ideology, but we have Christian Democrats with Social Democrats. But there wasn't any, any, any serious change in European Union. That is why, although these changes are interesting, they don't create the conditions for resolution of the crisis like Greece's.

\section{Third, diversity of the politics of European left forces}

The third point I would like to stress is that this differentiation has results that many radical left parties or movements from different countries have different position towards the European Union. Although more or less they have similar ideologies, they are in the same political family, in the same European current of thought etc. Even in one country you may have one position at one time and at other time you can have other position. I will give my personal example - when Greece was becoming a member of the European Union I was against it because I was a communist. But the majority of people were for. But history proceeded and we become a member of the European Union. After we left Communist Party and created Synaspismos and Syriza, we understood that we must have a fight with the other communist left parties, radical parties and so on so we can fight for reforms inside the European Union. So, we changed our position in a new situation. Then, after the explosion of 
беа за напуштање на еврозоната. Првин мислев дека овие предлози се парадоксални и чудни.

Не бев сигурен. Беше голема промена да се престане да се верува дека можеш да ги реформираш европските институции и политиката и да се залагаш за повлекување на Грција од тие институции. Имаше меѓународни економисти, како Кругман (Krugman) и Стиглиц (Stieglitz), што го поддржуваа истиот став. Ако Грција сака да преживее, мора да ја напушти еврозоната. Така, го сменив својот став. Го сменив доста доцна, две години по кризата. Јасно е дека се работи за иста личност, повеќе или помалку ја имав истата идеологија. Не мора да имаш ист став за овие работи. Радикалната левица во вашата земја може да ја поддржува одлуката да се биде дел од Европската унија иако се работи за капиталистичко интегрирање и да се биде во контакт со одлични левичарски партии, и сл. Во друга земја може да биде сосем обратно.

\section{Четврто, за Грекзит од еврото}

Четвртата поента што сакам да ја потенцирам е за значењето на конфронтирањето со еврозоната и на повлекувањето од неа. Има многу студии за односот на силните депресии во земјите. Има многу интересни написи за тоа, од кои би издвоил две студии што се особено значајни. Една е од „Капитал фанд“ (Capital Fund), насловот е "Капитал груп“ (Capital Group). Ja доби наградата „Вулфсон“ (Wolfson). Студијата од 2012 година е за напуштањето на Грција на еврозоната и за имањето сопствена валута. Другата студија ја направи грчкиот институт „Батсис.“ Значи, едната беше од „Капитал фанд,“ а другата беше од левицата, но и двете дојдоа до истите заклучоци. Првиот чекор е, потребата од голема циркулација на пари, многу пари во земјата, а мора да имате конкурентна валута. Тоа значи, мора да имате своја национална валута, но не можете да ја имате внатре во еврозоната. Тогаш the Greek crisis in 2009, I was reading the studies of different left leaning good Greek economists, like the professors Mariolis and Lapavitsas, who supported the withdrawal of Greece out of Eurozone. At first I found these proposals as paradoxical and strange

I was hesitating, it was a great change to stop believing that you can reform European institutions and policies and to strive for the withdrawal of Greece out of the same institutions. Then there were the international economists like Krugman, like Stieglitz who supported more or less a similar position. If it wants to survive, Greece must leave the Euro zone. So, I changed my position. I changed it quite late, almost two years after the crisis - I was the same person, I had more or less the same ideology as I had. So you can understand that it is not obligatory to have by the left forces in the different European towards euro or other European policies. You can understand that a radical left in your country can be in favour of being inside European Union although it is a capitalistic integration and having all these contacts with great left parties and so on, and in another country exactly the opposite, the exit.

\section{Four, on Grexit from euro}

The fourth point I would like to stress is on the meaning of confrontation with Eurozone and withdrawal from it. There have been many studies on many cases during the last century affecting national economies in a situation of deep depression. There are many interesting books and articles on this, but there are two studies with special importance. One is by Capital Fund, it was called Capital Group and it got the Wolfson Prize. The study from 2012 is on the chance of Greece leaving the Eurozone and having its own currency. And the other study was conducted by the Greek Institute Batsis. So, one was from a Capital Fund and the other was from the left, but both drew similar conclusions. So, the first step is that 
Грција може исто да биде ослободена од многу силното буџетско штедење бидејќи ви треба јавно производно трошење за да се мобилизира обновувањето на економијата. Ова значи дека не може да останете во еврозоната.

Реформите се потребни, но не такви какви што бараше „Тројката.“ „Тројката“ сака евтина држава. Што значи „евтина држава?“ Евтина држава значи помалку држава. Одговорот на радикалната левица е не повеќе држава, туку различна, ефикасна држава. Не може на Грција да ѝ помогнат приватниот капитал, странските инвестиции или инвестиции на десетте најбогати грчки семејства, единствено може државата. Грчката економија нема да ја придвижат Путин, Пекинг ниту Иран. Единствено ќе помогне нова држава која мора да е ефикасна, демократска, отворена, контролирана. Тоа е многу тешко но мора да се борите со тоа.

\section{Петто, излезот како интернационалистичка иницијатива}

Петта поента е повлекувањето во националните граници; за многумина тоа е решение. За нас кои сме во „План Б“ и имаме колку-толку сличен став како малцинство на Сириза, не се работи за движење кон затворање од националистички вид. Знаеме дека капиталистичката средина ќе остане капиталистичка и на меѓународно и на европско ниво. Не може тоа да го смени ситна државичка како Грција. Но можете да имате подобра позиција во оваа капиталистичка средина, во нашата позиција во меѓнародната поделба на производните сили. Ние не сакаме да имаме уништувачки филтер каков што беше наметна на Грција во врска со нејзината меѓународна економска соработка. За некои, европската интеграција е нешто објективно прогресивно, а нивната аргументација произлегува од традиционалниот марксистички there is a need for a big monetary circulation, a lot of money in the country, strong liquidity and the need for a competitive currency. That means you have to have your own national currency because it is impossible to have these preconditions inside the Eurozone. Then Greece can also be free of the very strong budgetary austerity because you need the public productive expenditure to mobilize the revival of the economy. That means that you cannot remain in the Euro Zone.

Reforms are needed, but not like the ones that are imposed by Troika. Troika demands a cheap state. What is the meaning of a cheap state? Cheap state means less state. The answer of radical left is not more state but a different state, an efficient state, and it cannot be the dreams for investments from abroad or the investments of the ten richest Greek families that can help Greece. It is mainly the state. It won't be the dreams for a help from Putin or Peking or Iran that can move the Greek economy. It is only one new state that must be efficient, democratic, open, controlled. That means something that is extremely difficult, but you have to struggle for it.

\section{Five, exit an internationalist initiative}

The fifth is that withdrawal means isolation into the national borders, for many it is such a thing. For us who are in "Plan B" and share more or less the same view as one minority part of Syriza, it is not movement towards a nationalistic closure. We know that the capitalistic environment will remain capitalistic environment on the international level and on European level. It cannot be changed by a tiny state like Greece. But we can have a better position in taking part in this capitalistic environment, in our position in the international division of productive forces. We do not want to have a kind of destroying filter imposed on Greece in relation with its international economic cooperation. For some, European integration may be something objectively 
(про-ленинистички) аспект, базирано на неговите два текста за британската окупација на Индија. Тоа значи дека, кога капиталот контролира една земја, дури и со варварски средства, тој ја развива. Според грчкото искуство, овој процес е многу реакционерен бидејќи силно ја разорува позицијата на земјата на меѓународната, за жал сѐ уште капиталистичка, соработка.

Ајде да го промислиме филтерот на еврозоната. На пример, би сакале да имаме поевтини јапонски автомобили затоа што сите во Грција претпочитаат јапонски автомобили. Треба да платите дополнителни даноци за јапонските автомобили, затоа се многу поскапи. Овој филтер за увозот е ист и за извозот. Грција би сакала да го извезува маслиновото масло, но денес Европската унија има политика која го отежнува извезувањето, а го олеснува многу увезувањето на маслиновото масло од Северна Африка, од поранешните европски колонии. Имам пријател економист, Христос Стергиоу. Во текот на длабоката криза имаше неколку обиди да се започнат некои нови и многу иновативни малечки претпријатија за извезување на посебна стока од Грција на посебни пазари. Тој и неговите пријатели имаа малечка фирма што почна да извезува многу квалитетно грчко масло во Канада. Пријателите што ја направија фирмата беа многу среќни. За 1 - 1,5 година фирмата се затвори, банкротира. Зошто банкротираше? Затоа што во тоа време многу различни региони, Брисел, а особено Берлин, сакаа силна Европа и скапо евро. Во тие две години, еврото растеше и имаше квалитетно масло од Грција, но имаше масло и од Чиле и Уругвај затоа што тие почнаа да култивираат масло.

7 Така Канада почна да купува маслиново масло од Чиле и Уругвај.

Можеме да бидеме многу меѓународно попозитивни ако се повлечеме од регионалната капиталистичка progressive and their argument is the traditional Marxist (proleninist) view, based on his two articles about the British occupation of India. It means that when capital controls a country, even with barbarian methods, it creates conditions for the revolution. According the experience of Greece, this process is very reactionary, because it deteriorates strongly the position of the country in international, unfortunately capitalist until now, economic cooperation.

Let's think of the Eurozone filter. For example, we would like to buy cheaper Japanese cars because many in Greece prefer Japanese car technology. One has to pay additional duties for a Japanese car but not for a French Citroen, although maybe he does not like it. This filter for imports is the same with our exports. Greece would like to make exports for its olive oil but today the European Union has a policy that makes it difficult for olive oil to be exported and it is very, very easy to be imported especially from the Northern African, ex-European colonies. I have a friend, Christos Stergiou, who is an economist. During the deep crisis there were some attempts for kick-starting some new and very innovative enterprise, for having exports of special goods from Greece to special markets. So, he and his friends created a very innovative exporting company that started to export very good quality Greek olive oil especially to Canada. The friends that created it were all happy. But after one and a half year suddenly this company was closed. Why did this company go bankrupt? Because it was a time when Berlin and Brussels wanted a strong and expensive - that means not competitive - Euro. Expensive for the Canadian importers and non-competitive in relation with Latin-American exporters. So Canada started buying olive oil from Chile and Uruguay.

So we can become more positively international if we withdraw from a regional capitalist integration, 
интеграција, особено од еврозоната, овој филтер, токсичен за нашите односи со светот. Бев изненаден кога во најлошите денови на грчката криза, во 2012 година, прочитав напис во „Фајненшал тајмс.“ Го напишал поранешниот директор на студии на Меѓународниот монетарен фонд и неговиот главен став беше дека е време проблемот за излегување на Грција од Еврозоната да се постави како централна дискусија. Тој е капиталист на многу високо ниво и го поддржува излегувањето на Грција од еврозоната („Грегзит“). Според него, главната причина за потребата на Германците и другите да ја тргнат Грција од еврозоната е што ако еден излезе, за две години Грција ќе има толку импресивен и спектакуларен економски и социјален прогрес, што ќе стане опасен пример и за останатите земји на периферијата на еврозоната.

\section{Шест, за екстремната десница и екстремната левица}

Шестата поента е - што е со екстремната десница и со екстремната левица, со радикалната десница и со радикалната левица? Што е со тоа? Има некоја конфузија, ако ги читате написите во „Ле Монд,“ „Фајненшал тајмс,“ „Њујорк тајмс,“ дури и на „Франкфуртер алгемајне цајтунг,“ тие зборуваат за популистичката закана за Европската унија, тие не разликуваат левица од десница. Го имаме феноменот на Грција, Сириза е главната партија, но не може да има парламентарно мнозинство без Независни Грци (Анел), партија што е многу националистичка, целосно анти-Скопје, анти-Турција, милитаристичка, итн. Како може да се објасни оваа абнормална коалиција? Зошто Ле Пен ја поддржуваше Сириза пред изборите? Веднаш по општинските избори во Франција, имаше интервју на еден од најпопуларните канали во Грција, „Мега канал,“ со Марин Ле Пен (Marine Le Pen). Дури некои пријатели especially from the Euro zone, this filter, toxic for our economic ties with the world. In the worst days of the Greek crisis in 2012, I read an article in Financial Times I cannot forget it. It was written by the ex-director of the Direction of Studies of the International Monetary Fund and his main position supporting the "Grexit" In his opinion, the main reason for the insistence of Germany and others to keep Greece inside Eurozone is that if Greece withdraws in two years' time Greece can have so impressive and spectacular economic and social progress, that will become a dangerous example for the other members in the periphery of Eurozone.

\section{Six, on extreme right and extreme left}

The sixth point is - what about the extreme right and extreme left, radical right and radical left? What about that? There is some confusion, if you read the articles in Le Monde, Financial Times, the New York Times, even "Frankfurter Allgemeine Zeitung" they are speaking about the populist threat to the European Union, they don't differentiate extreme right from left. We have the phenomenon of Greece, Syriza is the main party but it cannot have parliamentary majority without Independent Greeks, a party that is very nationalistic, very anti-Skopje, anti-Turk, militaristic etc.? How can one explain this abnormal alliance? Why was Le Pen supporting Syriza before the elections? Just after the municipal elections in France there was an interview on one of the most popular channels in Greece with Marine Le Pen. But even some friends from our initiative Plan B told me that she was very good.

So, I think we must study this problem. It is not easy to give an answer and there won't be only one answer but I think we must think again of it because sometimes, there is a conciliation between the left and the populism. You can say - left can be populist. The roots of populism are in Greece, it is its first written exposition. It was the 
од нашата иницијатива „План Б“ ми кажаа дека била многу добра.

Треба да го студираме овој проблем. Не е лесно да се даде одговор, а и нема да има само еден одговор, но мислам дека треба да размислиме повторно да го побараме затоа што понекогаш левицата и популизмот се помируваат. Можете да кажете дека левицата може да биде популистичка. Корењата на популизмот се во Грција, во тиранијата. Тоа значи дека водачите во транзициониот период од олигархија во демократија доаѓаат на власт со нивните приватни војски и водат политики што им одговараат на сиромашниот народ, па затоа имаат силна поддршка, но претставува катастрофа за демократските институции и перспективи на градовите-држави.

Ајде да ги откриеме кои работи се популарни. Ајде да се концентрираме и да работиме на нив, за да не им ги препуштиме на реакционерните сили, како што направија социјалдемократите во Франција. Не им ги давајте сиромашните луѓе како подарок на ЛеПен и ксенофобните организации. Левицата е таа што мора да ја има радикалната агенда за социјална промена. Ова прогресивна агенда нека ги има дистинктивните демократски и хуманистички особености што, нека се направи јасна разлика и конфликт со расистичките анти-имиграциони политики на екстремната десница. Подемос во Шпанија се бореше генерално против „корупцијата“ и конечно нивните лидери беа обвинети за корупција. Тие исто така како главна поента ја имаа генерално „новата партија“ и ова беше искористено од уште помлада партија и од Подемос, но со неолиберална идеологија, Циудади-

Мислам дека еден од најголемите проблеми во политиката е апстрактното размислување. Апстрактното мислење помага да се предизвика реакција. Вие сте
Tyranny. It means that leaders in the transitional period from oligarchy to democracy get in power with their private army and have policies that are favourable to the very poor people, hence having a strong support but causing a catastrophe to the democratic institutions and perspectives of the city states.

Let's find what the more popular things are. Let's concentrate and intervene on them and not leave reactionary forces do that, as social democrats have done in states like France. Don't give the poor people as a gift to Le Pen and the xenophobic organisations. It must be the left who has the radical agenda for a social change. And let this progressive agenda has as distinctive democratic and humanistic characteristics, that make a clear differentiation and conflict with the racist antiimmigration policies of the extreme right. Let our policy based on concrete proposals, note general declarations. The Podemos in Spain were fighting against "corruption" in general and finally some of their leaders were accused of corruption. Or they had as their main point the "new party" in generally and this was used by a party younger even than the Podemos, but with a neoliberal ideology, the Ciudadinos.

I think one of the biggest problems in politics is the abstract thinking. The abstract thinking helps the reaction. You are not radical regarding only the general ideas - liberation and emancipation, and not austerity and all these things, but on the details. The radical left must remain radical left on the details, too. Sometimes the details bother you and you see them as something like an obstacle, so you leave them, you don't speak about the details. Concerning the relations of Athens with Skopje, the problem is not only that the left is supporting a friendly solution - we must have the ability to propose the concrete steps towards the solution. We cannot be godfathers and to give the name of a country. 
радикални не во генералните идеи - ослободувањето, еманципацијата, штедењето и сите тие работи, туку во однос на деталите. Радикалната левица исто така мора да остане радикална во однос на деталите. Понекогаш ве нервира деталното и го гледате како некаква пречка, затоа, го оставате и не зборувате за деталите. Во врска со односот на Атина со Скопје, не е проблемот само што левицата подржува пријателско решение - мора да ја имаме способноста да предложиме конкретни чекори кон решение. Не можеме да бидеме кумови и да ја именуваме земјата. Првото нешто што треба да го направите е да престанете да се плашите. Ако ние престанеме да се плашиме од вас, а вие да се плашите од нас, ние да престанеме да се плашиме од националистите во нашата земја, а вие во вашата, мислам дека се отвора пат до решението, но никој не зборува за тоа. Мора да бидете радикално лево ориентирани во однос на деталите и мислам, не треба да ги избегнувате, да бегате од проблемите. Мислам и дека радикалната левица не смее да биде затворена како партија или политичка иницијатива. Мора да биде културна иницијатива што ќе го смени начинот на кој размислуваат луѓето и која му се спротивставува на капитализмот, не само оној што го претставуваат Mеркел (Merkel) или Самарас, туку на оној во нас. Тој е вгнезден во нашиот начин на размислување и нашите вредност иако сме левоориентирани.

Ке завршам со кажувајќи дека пред една година имаше силна расправа меѓу Самарас и Ципрас, меѓу Нова демократија и Сириза. Што беше разликата? Тоа беше прашањето за тоа кој има авторско право на изразот „Нова Грција.“ Дали е толку важно, толку радикално да се има Нова Грција? Тоа е апстрактно, тоа е ништо. Тоа беше смешно и дури и луѓето почнуваа да се смеат дали воопшто имаме проблем. Значи, не апстрактното - детаљот.
And the first thing that you have to do is stop being afraid. If we stop fearing you and you stop fearing us, we stop fearing the nationalists in our country and you in yours, I think the solution is open but no one speaks about that. So you must be radical left on the details and I think, not to escape from them, escape from the problems and I think also the radical left must not be closed as a party or political initiative. It must be a cultural initiative that is changing the way people are thinking and is fighting with capitalism not only with Merkel or with Samaras but with capitalism inside our brain and heart. It's embodied in our way of thinking and our values although we are left.

I will finish this saying that it was a year ago a very strong dispute between Samaras and Tsipras, between the New Democracy and Syriza. What was the difference? It was the question of who had the copyright for the expression "New Greece." Is it so important, if radical to have New Greece? It's abstract, it's nothing. It was funny and even the people were starting to laugh whether we have a problem. So, not the abstract- the detail. 